\title{
砂州形状の特性と平水時の流路構造 RELATIONSHIP BETWEEN CHARACTERISTICS OF BAR MORPHOLOGY AND RIFFLE-POOL STRUCTURE
}

\author{
寺本敦子 $1 \cdot$ 辻本哲郎 2 \\ Atsuko TERAMOTO and Tetsuro TSUJIMOTO \\ 1正会員 博 (工) 松江工業高等専門学校助手 環境・建設工学科 \\ ( ₹ 690- 8518 島根県松江市西生馬町14-4) \\ 2正会員 工博 名古屋大学大学院工学研究科教授 社会基盤工学専攻 \\ ( ( 464-8603 愛知県名古屋市千種区不老町)
}

\begin{abstract}
Riffle-pool structure gives important habitat to various organisms in a river. Although many types of riffle-pool structure are previously defined by ecologists, the deciding factors of types are unfound. We focus on riffle-pool structure based on alternative bars and indicate the deciding factor of it though the investigation of typical feature types of alternative bars

Firstly, we conducted flume experiments and numerical simulations and investigated the existence of two types of alternative bars, which formed from flatten bed by steady discharge. One is developing from flatten bed; the other is formed after multiple bars are developed. And they have different features. Then, we indicated the change of bar morphology caused by different discharge from the discharge that initial bar forms. As results, the existence of three types of bar feature is indicated, and it is clear that riffle-pool structure based on these types of alternative bars is different from each other.
\end{abstract}

Key Words : alternative bars, riffle and pool structure, bar migration, numerical simulation flume experiment

\section{1.はじめに}

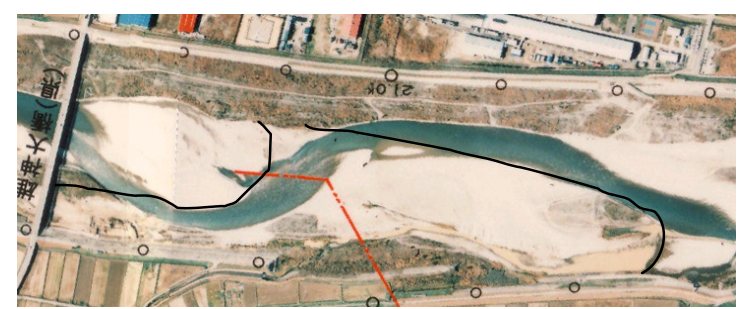

图-1 交互砂州河道の事例A(富山河川国道事務所提供)

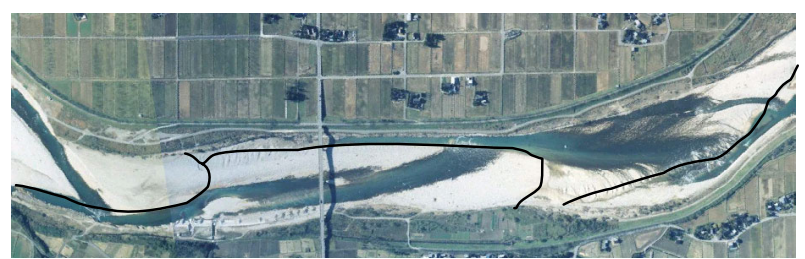

图-2 交互砂州河道の事例B(富山河川国道事務所提供)

近年 , 河道内砂州が河川における生態系や物質循環に 対して樣々な場を提供することで重要な役割を担ってい ることが着目されている . 図-1，2て示す交互砂州の樣子
が異なるように, 実際の河川においては, 樣々な特徵を 持つ砂州力存在しており，砂州形状，構成材料などの砂 州の物理的特性によって河道内環境に果たす役割が異な ることが考えられる．しかし，現段階では，砂州の特徵 を決める要因など詳細は未だ明確になっていない .

一方で, 砂州上に形成される平水時の流路，流路内に できる瀬と淵に着目すると，これもまた河道内生態系に 重要な役割を果たしている.これまでに瀬と淵の形態や 䒓の配置の違いにより瀬濎構造の分類か行われてきた" が, 樣々な形態力現れる機構について十分な知見がい のか現状である . 瀬縉構造は交互砂州地形と深く関係し ているが, 交互砂州を基盤とする低水時の流路に着目し た場合, 砂州によって水際環境力潩なることか指摘され ていたり゙2), 図-1，2のように砂州の前縁線(図中の黑線) と低水時の流路位置の関係か異なったりしている．した がって, 同じ交互砂州上にできる低水路でも，瀬縉構造 の特徵が異なることが考えられる .

沖積地河川では，一般的に，平均年最大流量で形成さ れる砂州を基盤として平水時の流路か形成されていると 考えられている゙．しかし，河川には樣々な流量が流れ ており，これがどのように砂州形状に影響を与えている 
表-1 実験ケース(単位 : m, s)

\begin{tabular}{|c|c|c|c|c|c|}
\hline Case & $\mathrm{A}$ & $\mathrm{B}$ & $\mathrm{C}$ & $\mathrm{D}$ & $\mathrm{E}$ \\
\hline$Q$ & 0.0008 & 0.0010 & 0.0015 & 0.0020 & 0.0030 \\
\hline$h$ & 0.0062 & 0.0070 & 0.0090 & 0.0107 & 0.0136 \\
\hline$B / h$ & 81.275 & 71.090 & 55.738 & 46.902 & 36.774 \\
\hline$\tau_{*}$ & 0.042 & 0.048 & 0.062 & 0.073 & 0.094 \\
\hline Fr & 1.059 & 1.083 & 1.128 & 1.161 & 1.209 \\
\hline mode & $2-3$ & 2 & 1 & 1 & 1 \\
\hline $\mathrm{L}$ & 0.8 & 1 & 1.5 & 1.5 & $1.5-2.5$ \\
\hline
\end{tabular}

*mode : 線形不安定解析による初期発達砂州モ一ド数

$* \mathrm{~L}:$ 線形不安定解析による初期発達砂州波長

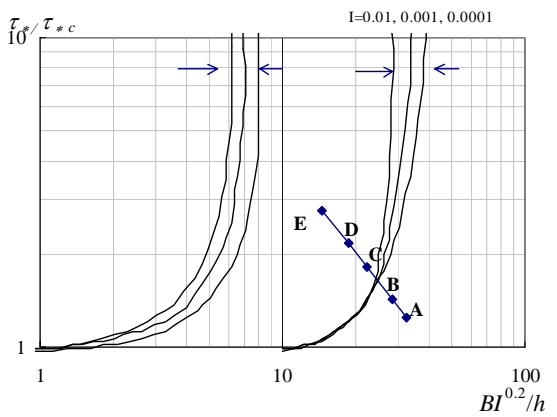

図-3 砂州の領域区分図(黑木・岸4)修正) と実験条件

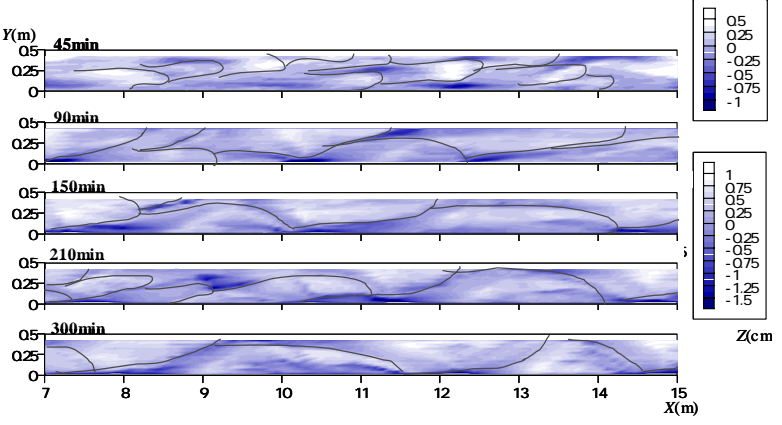

図-4 砂州形成実験ヶースBにおける河床高時間変化

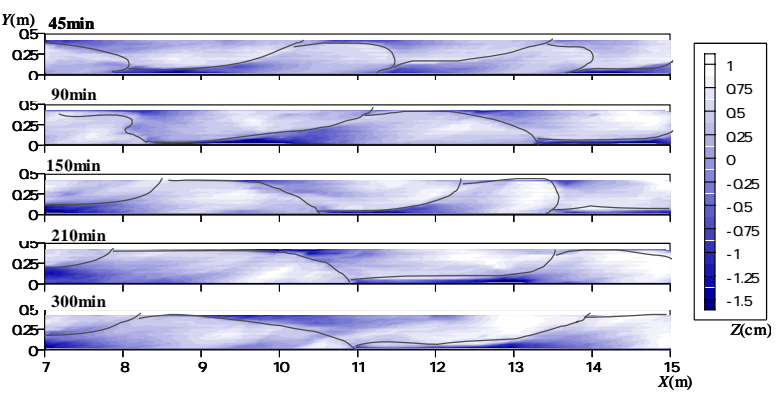

図- 5 砂州形成実験ケースDにおける河床高時間変化

かは明らかになっていないし, 出水時の流量, 平水時の 流量の変化によってどのように瀬滆構造力変化するかも 明確でない，従って，一概に平均年最大流量で形成され る砂州を瀬淵構造の基盤と考えてよいかは疑問である.

これらを踏まえて, 本研究では, 交互砂州の特徵を決 める要因から交互砂州の特徵による瀬淵構造の違いにつ いて調べる．まず，一定流量通水時に形成される砂州の 特徵を数値解析およひ室内水路実験を用いて示し，光の 後, 平衡状態の砂州上に砂州形成流量とは別の流量を通 水した時の砂州地形の変化について数值解析を用いて検 討する . 砂州の地形変化を検討することにより典型的な
砂州地形を見出し，これらについて平水時の流路構造を 調べる .

\section{2. 一定流量通水時における砂州地形形成過程と 砂州の平衡形状}

ここでは，一定流量通水時の砂州地形の形成過程及び 平衡状態到達時の特徵について検討する . 検討にあたり， 水路幅 $50 \mathrm{~cm}$ ，水路勾配 $1 / 100 ，$ 河床材料の平均粒径 $0.88 \mathrm{~mm}$ の条件下で流量を変化させ，表-1に示す砂州形 成条件内の5ケースを用いる.ケースAからEは, 複列砂 州から単列砂州形成領域内にあり，修正した黑木・岸 の領域区分図上には図-3のようにプロットされる .

本章では，実現象を見出すために水路実験を，また， 実験結果と比較し有用性を確認した上て実験結果を補足 するために数值解析を行った .ただし，水路実験を行う 流量が大きくなると, 通水初期に水路に形成された砂州 のうち上流部分の砂州は下流入流下し, 上流区間のある 程度の範囲には新たな砂州か形成されない，光の区間は 砂州を形成し続けるために必要な助走区間と言え，実験 においても数值解析と同樣に5)流量が大きくなるほど長 く必要となる.今回用いた名古屋大学大学院の実験水路 長は20mであるが, 交互砂州の形成について実験できる 流量はCaseDか限界であったため，本検討の最大流量で あるCaseEは , 数值解析のみの検討となっている .

実験では，水位と河床形状をKEYENCE製の超音波式 変位センサ, CCDレーザ変位センサを用いて計測し,さ らに水路上部からデジタルカメラを用いて砂州の樣子を 撮影した。

また, 本研究で用いる数值解析は, 名古屋大学大学院 水工学講座において著者らか開発してきたNH2Dモデル を用いた . 本モデルの砂州形成過程の再現性は , 著者ら の論文吕を参照されたい .

本研究において, 砂州波長と波高は, 隣接する砂州前 縁線下流端間の長さと横断方向高低差の最大值を各砂州 で算出した上で, 波長については対象区間内の砂州の平 均値とし, 波高については平均值と最大值の両方を算出 している。

\section{（1）砂州形成過程}

結果の一部を図-4，5に示すように，CaseA，Bは，線 形不安定解析の結果と同樣に数值解析, 水路実験ともに 通水初期に複列砂州の形成され, 砂州の発達と共に最終 的に交互砂州への移行が確認された．关れに対し， CaseC，D，Eは通水初期から交互砂州の発達が見られた . 結果の一部を図-6，7に示すように，砂州波高の時間 変化を見ると, CaseC, D, Eは砂州波高がすぐに発達し 平衡状態入到達するのに対し, CaseA, Bでは, 複列砂 州か形成されている間, 波高は低い值を保ち, 兴の後発 達することか確認された . 数值解析は，実験に比べ砂州 


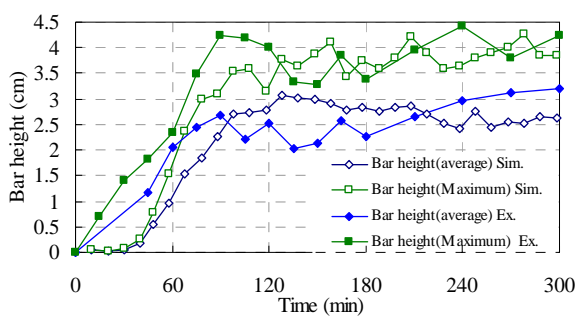

図- 6 砂州形成実験ケースBにおける河床高時間変化

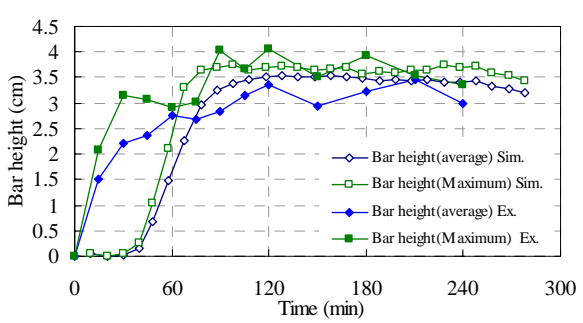

図- 7 砂州形成実験ケースDにおける河床高時間変化

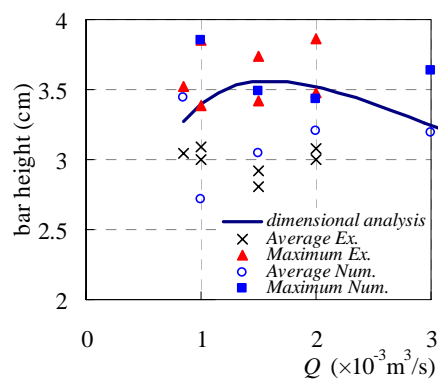

図-8 流量と砂州波高の関係

か発達し始めるまで多少の時間を要するが, 発達し始め てからは, 波高 , 波長ともに実験と同じであることを確 認している.

\section{（2）砂州の平衡形状}

流量を一定で流し続けたとき，流量によって個々の砂 州の值にばらつきがあるものの, 砂州波高, 波長の平均 值はおおよ光一定值に到達する平衡状態に到達する . こ こでは, 平衡状態ての交互砂州形状の特徴を検討する .

各流量通水時の砂州波高の数值解析結果および実験結 果を图-8に示すと，流量間に大きな違いが見られないこ とがわかる. 本実験条件下では，池田6)次元解析によ る式を用いて算出した波高値も同樣な值を示し，流量に よる砂州波高の差がないことがわかる . また，平均波長 を検討した結果も，流量による違いが見られなかった .

乥こで, 波長 , 波高以外の砂州形状の違いを見出すた めに, 藤田ら゙カ砂州形成実験で見出したかまぼこ型形 状に着目し縦断方向に平均した横断地形の特徵を水深で 無次元化して調べた .ただし，河床高を縦断方向に平均 するにあたり，数值解析においては砂州形成領域力長く 多数の砂州が形成されているため長い領域で行い, 実験 においては砂州形成領域か短いため，隣り合う砂州二個 分の領域で行った . 兴の結果を図-9に示すと，実験およ ひ数值解析ともに, 同じ交互砂州でも, 最初から交互砂

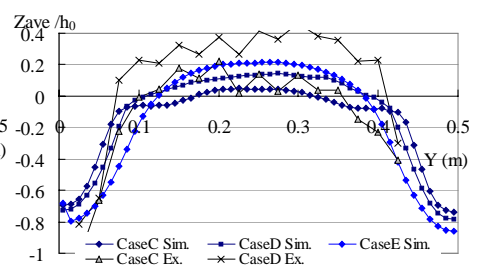

図 9 縦断方向平均無次元横断河床

表-2 実験ケース(流量 : $\mathrm{m}^{3} / \mathrm{s}$ )

\begin{tabular}{|c|c|c|c|c|c|c|}
\hline Case & BD & BE & DB & DE & EB & ED \\
\hline 初期地形形成流量 & \multicolumn{2}{|c|}{0.0010} & \multicolumn{2}{c|}{0.0020} & \multicolumn{2}{c|}{0.0030} \\
\hline 通水流量 & 0.0020 & 0.0030 & 0.0010 & 0.0030 & 0.0010 & 0.0020 \\
\hline
\end{tabular}

州か溌達したものと複列砂州の発達後移行してできたも のでは縦断方向平均横断河床の特徵に違いがあることが わかった . 前者は, 壁際付近の狭い範囲か汕側ともに掘 れているのに対し，後者は，兴のような特徵を持ってい ない. 特に流量が多いほど局所的に壁祭力淈れている傾 向があることが分かる. 無次元量で示した縦断方向平均 横断河床高の高低差は流量により変化しないが, 流量に よって波高に違いがないことを考えると，流量が少なく 水深が浅いほど横断河床形状の高低差は小さくなってい るため, 砂州形状に対して縦断方向に平均した横断形状 が果たす役割は，流量が大きいほど大きくなると言える .

\section{3. 流量の変化が及ぼす砂州地形への影響}

次に, 流量の変化に伴う砂州地形の変化を調べるため, 数値解析を用い，2章で示したCaseB，D，Eの平衡状態 の砂州を初期地形として砂州形成流量とは異なる流量を 通水して地形の変化を調へた .ここでは, 表-2に示すよ うな流量の組み合わせを用いる .

\section{(1) 流量増加ケース}

図-10，11に例を示すように，流量力増加する場合， 10分後には砂州は進行するとともに流量に見合った形人 と変化する．また，図-12，13に示すように，砂州波高 は時間力経過してもあまり変化しないのに対し，縦断方 向平均横断河床形状は, 流量に見合った特徵へと変化し ている．例えば，複列砂州から交互砂州へ発達した CaseBD , BEの初期河床は , 縦断方向平均横断河床形状 における壁近傍での洗掘が見られないが, 時間力経過す るとともに砂が水路中央部に集まり壁近傍が洗掘される . CaseDEにおいても, 初期河床の縦断方向平均横断河床 形状における壁近傍の洗掘力顕著であるにもかかわらず， 流量の増加に伴い乥の特徵か強く現れるようになる. 従って，初期状態が光れより小さい流量で形成された砂 州ならば，すぐに光の流量に応答し通水流量に応じた砂 州の平衡状態へと遷移すると言える。ただし，ここでは， 通水流量力交互砂州形成領域内にあるため, 通水流量が 複列砂州形成領域内の場合の検討か別途必要である . 


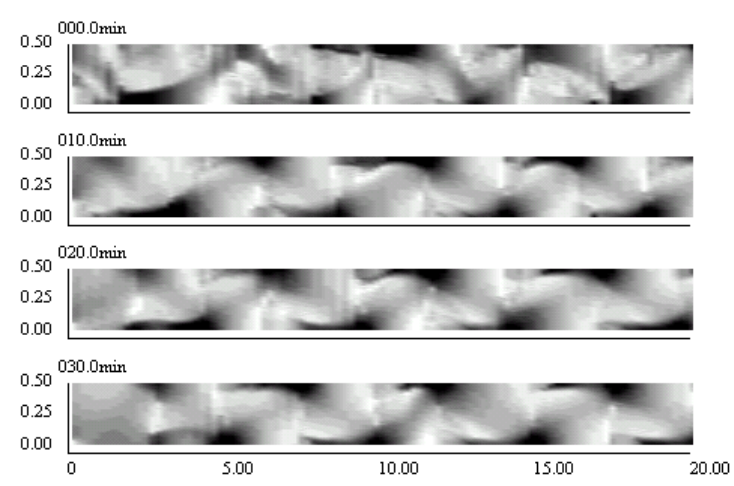

図-10 河床高時間変化 (CaseBD) (単位 : m)

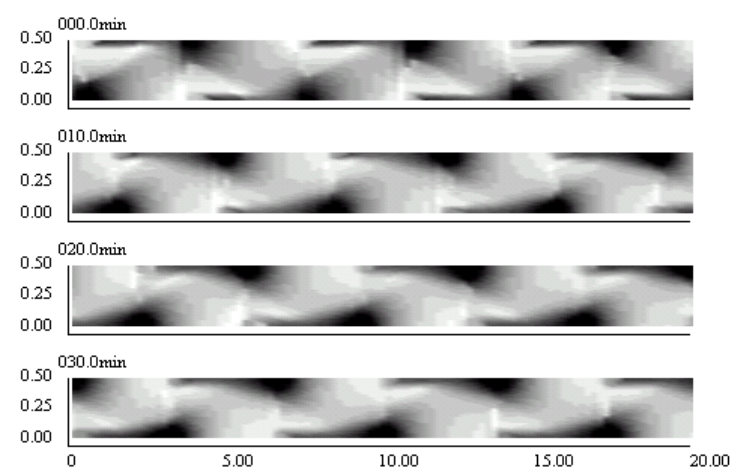

図-11 河床高時間变化 (CaseDE) (単位 : m)

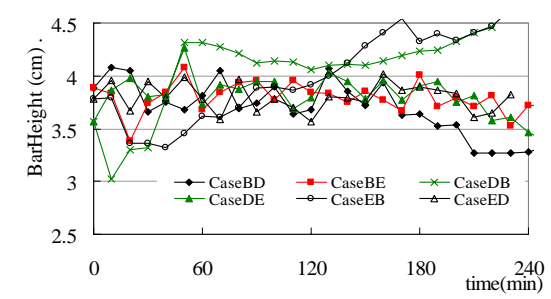

図-12 最大砂州波高時間変化

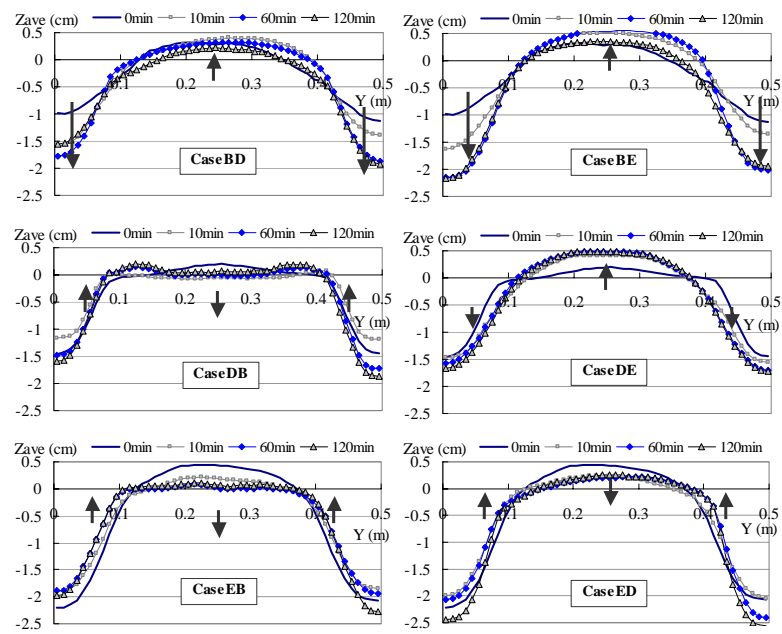

図 13 縦断方向平均横断河床形状の時間変化

（2）流量減少ケース

図-14〜16に河床高時間変化を示すように，初期河床 形成流量より通水流量が少ない場合，通水流量がどのよ うな流量なのかて砂州地形の变化傾向が異なる。

CaseDB，EBのように通水流量力複列砂州形成条件に 入っている場合にCaseD，Eの単列砂州形成条件下で形 成された交互砂州を初期河床とすると，図-17，18にあ
るように流路は砂州の一部に限定され，砂州前縁線と交 差する . 砂州が進行する場合も流線は砂州前縁線と交差 するが, 砂州全体で砂力動き，砂州前縁線付近に砂力堆 積する . 流量が咸少したことにより流路力限定されかつ 砂力動く部分力限定されてしまうケースでは, 前緑線よ りも上流部分に堆積域ができており，このことにより， 砂州は進行せずにゆっくりと後退しているように見える . また，図-13に示す縦断方向平均横断河床形状は，壁近 傍の洗掘の埋め戻しが起こり，蒲鉾型形状か明確でない CaseBの特徵にやや近づくような変化が見られる .

これに対し，CaseEDでは，図-16の河床高時間変化， 図-13の河床形状特性の变化から見られるように, 砂州 形成流量より通水流量が少ないにもかかわらず，砂州は 進行し, 通水流量に見合った砂州力形成されている。こ のとき，流線は図-19のようになっており，砂州の前縁 線と交差し多少陸化している部分があるがほとんど水面 下であるため, 結果として砂州は進行している. CaseE で作られた砂州地形の特性は, CaseDの平衡形状の特性 と似ているため, このような変化か起こると考えられる．

\section{(3) 流量の変化に対する砂州地形の変化}

(1)，(2)の結果を通して , 次のことが言える . 今回対 象とした流量によって砂州波高力変化しない河道条件下 では, 一定流量通水時，平坦河床から形成される平衡河 床形状特性によって, 初期河床として他の流量下での平 衡河床形状を用いるときの変化が決まる. 通水流量か交 互砂州形成条件下となる流量の場合，初期河床形状がど のような交互砂州でもすぐに流量に見合った砂州へと移 行する. 弚れに対し, 通水流量力複列砂州形成条件下と なる流量の場合，初期地形の影響を強く受ける. 初期河 床形状が通水流量より大きな流量て形成された交互砂州 である場合，砂州の上流側に土砂を堆積し砂州を後退さ せ砂州の形状特性を大きく変化させる．

したがって, 実河川における交互砂州地形は, 単列砂 州形成条件下の出水力瀕繁に起こる河道と, 複列石少州形 成条件下の出水力頻繁に起こる河道と，乥の中でもまれ に単列砂州形成条件下の出水を経験する河道で光の特徵 を分けることができると考えられる .

\section{4. 平水時の流路の特徵}

ここでは, 簡単に河道内砂州を捕らえるため, 出水後 の砂州地形は, 出水時の流量ハイドロによらずピーク流 量で砂州地形が決まると考え，これまでに見出した砂州 地形に対する平水時の流路構造の変化を議論する .

\section{(1) 検討ケース}

第3章の結果をうけ, 本研究て検討した交互砂州地形 のうち典型的なものとして次の3ケースから得た砂州形 状を選出し，平水時の流路構造を検討する．一定流量通 


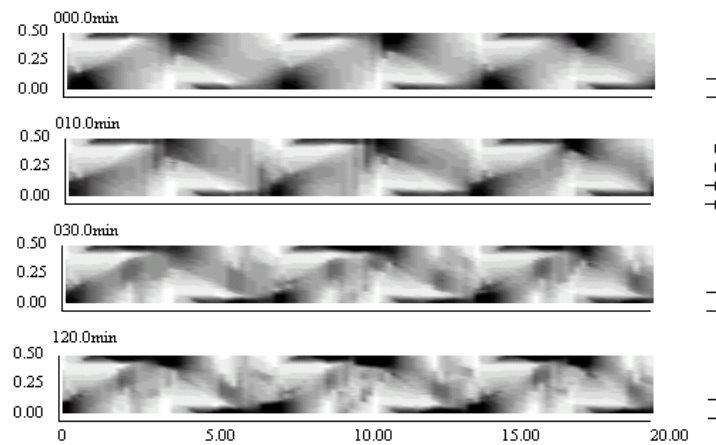

図-14 河床高時間变化 (CaseDB)

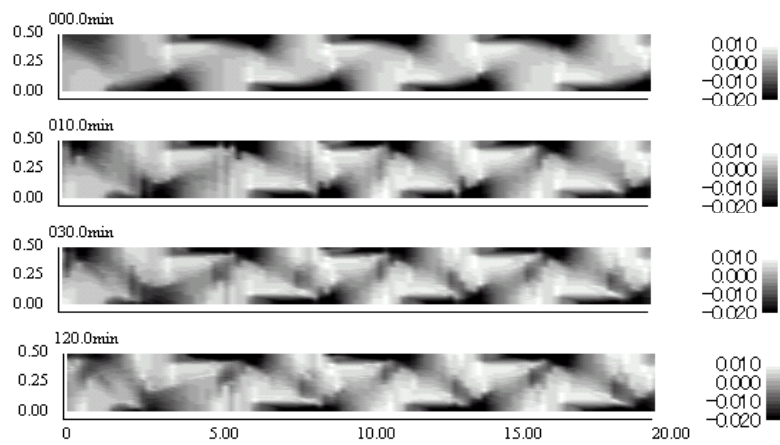

図 15 河床高時間変化 (CaseEB)

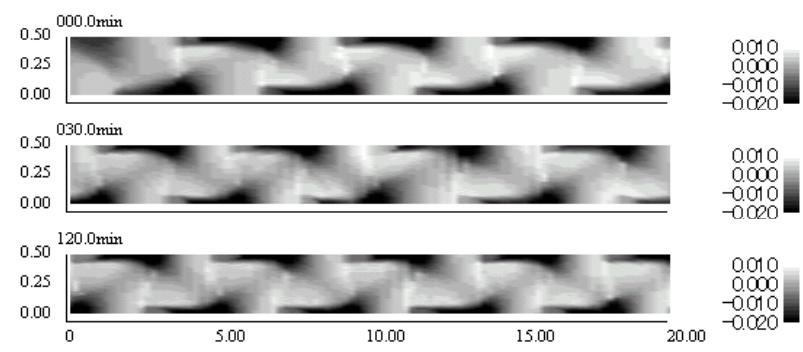

図-16 河床高時間変化 (CaseED)

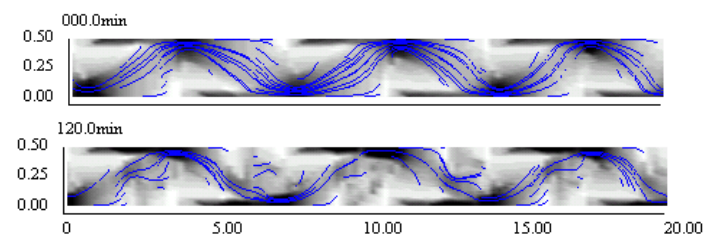

図-17 河床高と流線 (CaseDB)

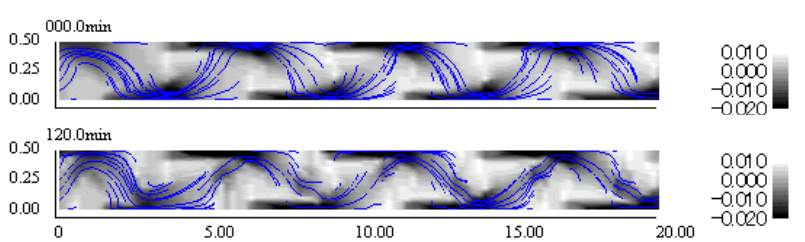

図-18 河床高と流線 (CaseEB)

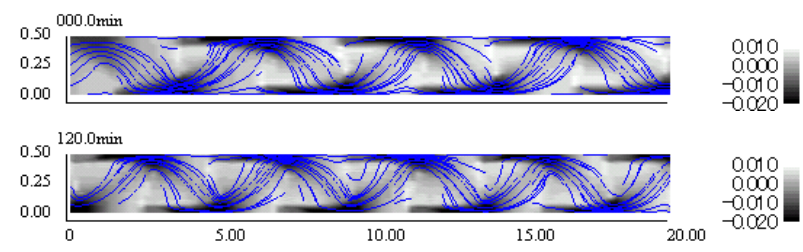

図-19 河床高と流線 (CaseED)

水時に平坦河床から形成される交互砂州のうち，明確な 蒲鉾型形状を有するものとしてCaseEを，乥うでないも のとしてCaseBを，蒲鈗型形状の砂州上に複列砂州形成
条件下の流量が流れた地形としてCaseEBを用いる .

平水時の流量は, 砂州上の砂がほぼ動かない流量 $0.00015 \mathrm{~m}^{3} / \mathrm{s}$ と产の倍の $0.0003 \mathrm{~m}^{3} / \mathrm{s}$ を用い, 流量の増加に 伴う流路構造の变化についても検討を行う.

\section{（2）流路の特徵}

図-20〜22に各ケースのフルード数およびベクトル図 を，図-23に低水路に沿った河床高と水位，フルード数 の変化を示す . これらのグラフを見ると, 平水時の流路 となる位置は, どの砂州地形を用いても低水流量によっ て流路幅は異なるか洞じ位置に形成されることがかかる .

CaseEの砂州上の流路は深ばれ部て幅力狭く，砂州前 縁線を分断して浅い場所から深ぼ部入落ち込み，前縁 線付近におけるフルード数力幅広い範囲で高い値を示し ている．これに対し，CaseBの砂州上の流路は砂州の前 縁線を沿っており, フルード数は, 隣り合う砂州前縁線 か交差する点付近の比較的幅力狭い場所で高い值を示す． また, CaseEBの砂州上の流路は, 砂州前縁線と低水路 位置の関係はCaseEに近いものの, CaseBの砂州上に形 成される流路の特徵に近くなり，川幅は狭く，長い範囲 でフルード数か高い值を示しているのがわかる.

上記の結果より, 水深か比較的浅くフルード数が1以 上の射流で, 淵は水深が深くフルード数が1以下の常流 であるとすると, 砂州の形成履歴, 砂州形状により瀬淵 のパターンは変化すると言える . また , 瀬淵か現れるパ ターンは, 低水時の流量によってあまり変化しないが, CaseEB，Bの砂州上に形成される流路に沿ったフルード 数が流量の増加に伴って全体的に1に近づくことを考え ると砂州形状によって瀬淵構造力明確に現れる流量には 限界があることが考える。

\section{5 ．結論}

本研究により次のことか明らかになった .

a) 平坦河床から発達した交互砂州は, 複列砂州を経由 したものと光うでないもので形状の特徽が異なり，後 者は藤田らが見出した蒲鉾型形状を明確に有する．

b) 平衡形状の砂州に砂州形成流量より大きな流量が流 れたときには，すぐに通水流量の平衡状態入遷移する． c) 平衡形状の砂州に砂州形成流量より小さな流量が流 れたときには，光の流量次第て変化が異なる.交互砂 州形成条件下の流量では砂州か進行して通水流量の平 衡状態へ遷移するが, 交互砂州形成条件下の流量より 少ない複列砂州形成条件下の流量になると砂州は進行 せず，砂州の上流側に堆積域ができ，砂州は後退する． d) 低水時の瀬淵構造は, 砂州形状に依存し, 蒲鉾型形 状を有するか否か, 有していても产の上に他の砂州形 成条件の流量を経験したか否かて特徵か变化する.蒲 鉾型形状を有すると砂州前縁線と低水路位置の関係は， 半波長ずれた形になり，光うでない場合は，低水路は 

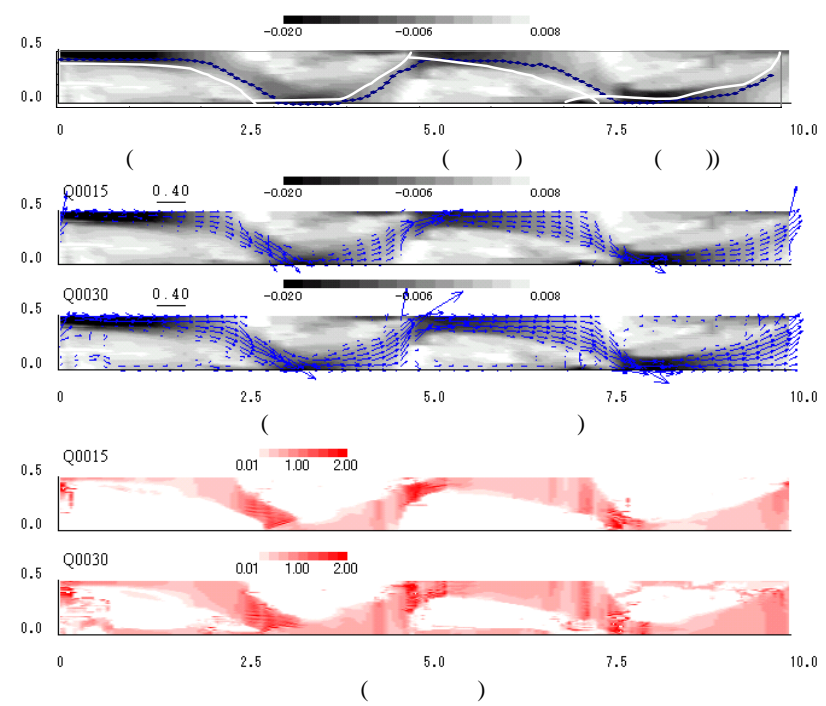

図 20 低水流路の特徵 (CaseB) (単位: m)
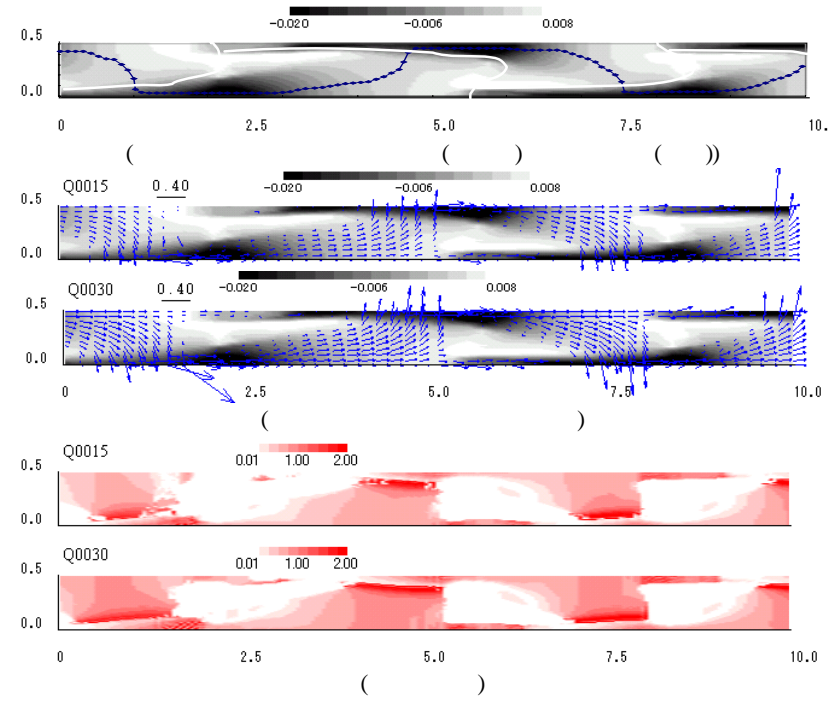

図-21 低水流路の特徵 (CaseE) (単位: $\mathrm{m}$ )

前縁線に沿って形成される.また，複列砂州形成条件 下の流量が流れたか否かで流路幅力比較的狭い瀬がで きるか否かが異なる。

b)，c）を踏まえると，実際の河道内砂州の地形は，出 水ごとに変化し, 必ずしも平均年最大流量程度て形成さ れる砂州の特性で瀬淵構造が決まっているとは限らない とわかる.特に年最大流量や頻繁に発生する出水砂州 形成条件のどれに該当するかが重要となる. 単列砂州条 件下の出水力瀕繁に起こる場合, せいぜ複列砂州形成 条件下の出水しか起こらない場合，弚の中でも単列砂州 形成条件下の出水を経験しているか否かて砂州地形の特 徵, 低水時の流路の特徵力変化する。

今回の検討は各流量時の平衡砂州波高に相違がない ケースを取り扱っており，条件か限定された場で議論 となっている可能性がある. 波高に違いがあるケースも取り扱い一般的な議論に発展 させる必要がある . また, 出水時の流量八イド口の影響 を考慮せず一定流量て形成される砂州形状て議論を行っ ているため, 流量ハイドロの考慮の必要性についても検

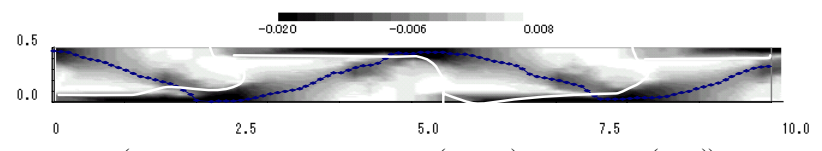

(河床高コンターと低水路ライン(青色線), 砂州前縁線(白線))
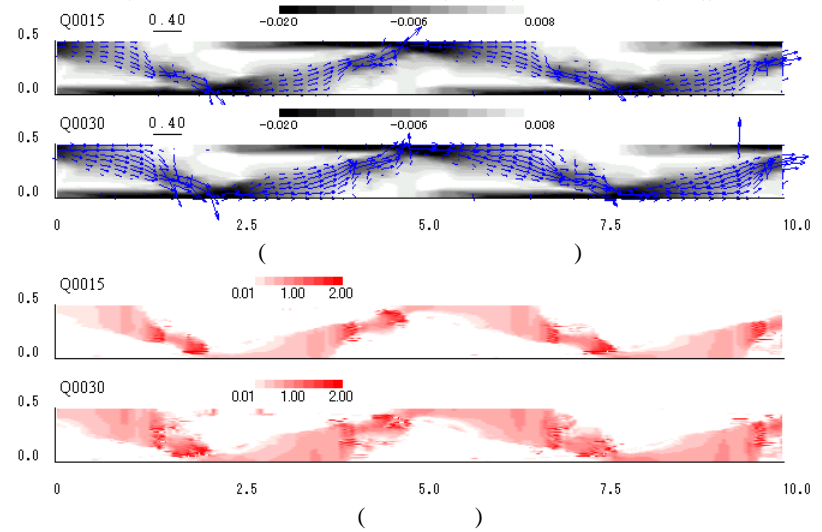

図 22 低水流路の特徵 (CaseEB) (単位: m)
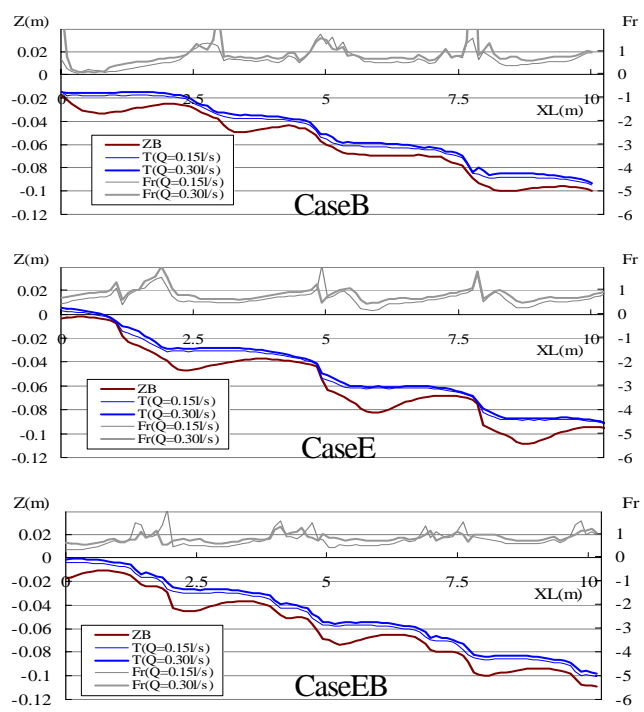

図 23 低水路ラインに沿った水面形とフルード数の変化

討し，実際の河道への議論の適用性を高める予定である .

謝辞 : 本研究は, 科学研究費補助金 (若手研究(B)) の助成の もと行われた . また，実験については名古屋大学大学院博士前 期課程(現・奥村組)の松井宏充君に協力いただいた . 記して謝 意を表する .

\section{参考文献}

1) 例えば, 水野信彦, 御勢久右衛門(沼田誠 監修) : 河川の生態学 補訂版，築地書館，pp.4-13，1993.

2) 知花武佳, 佐々木学, 辻本哲郎: 交互砂州か形成された河道に 生じる水際環境に関する研究, 応用生態工学会第七回研究発表 会講演集, pp.231-234, 2003 .

3) 山本晃一 : 構造沖積河川学-关の構造特性と動態- , 山海堂, pp149-154, 2004 .

4) 黑木幹男, 岸力 : 中規模河床形態の領域区分に関する理論的研 究, 土木学会論文報告集,第342号, pp .87-96, 1984 .

5) 寺本敦子, 辻本哲郎 : 砂州の形成過程に関する数値計算手法, 応用力学論文集，第7巻，土木学会，pp.975-982，2003。

6) 池田駿介 : 単列砂州の波長と波高, 第27回水理講演会論文集, pp.689 695, 1983 .

7) 藤田裕一郎・村本嘉雄・堀池周二 : 交互砂州の発達過程に関す る研究, 京都方災研年報, 第24号B-2, pp.411 431, 1981 .

(2005.9.30受付) 